\title{
TAXONOMIC STUDIES IN THE MICONIEAE (MELASTOMATACEAE). XIV. SPECIES OF MICONIA SECTION SAGRAEA THAT OCCUR IN THE GREATER ANTILLES AND ADDITIONALLY IN THE LESSER ANTILLES AND/OR CONTINENTAL REGIONS
}

\author{
Walter S. Judd \\ Dept. of Biology and Florida Museum of Natural History \\ University of Florida \\ Gainesville, Florida 32611-7800, U.S.A. \\ lyonia@ufl.edu
}

\section{Gretchen M. Ionta}

\author{
Dept. of Biological \& Environmental Sciences \\ Georgia College and State University, CBX-081 \\ Milledgeville, Georgia 31061, U.S.A. \\ gretchen.ionta@gcsu.edu
}

\author{
Lucas C. Majure \\ Desert Botanical Garden \\ 1201 N Galvin Parkway \\ Phoenix, Arizona 85008, U.S.A. \\ Imajure@dbg.org
}

ABSTRACT

\begin{abstract}
The systematics of three species of Miconia sect. Sagraea from the Greater Antilles, which also occur in the Lesser Antilles and/or continental regions, is investigated. These taxa, representing lineages of likely independent dispersal into the Greater Antilles, are here taxonomically revised, including for each a description, nomenclatural information (including a new name, Miconia sciaphila, and two new combinations, M. berteroi and M. septuplinervia), specimen citations, and an eco-geographical characterization. These species are compared with members of two species-rich clades of sect. Sagraea of independent diversification in the Greater Antilles: the Clidemia oligantha/C. leucandra complex (comprising seven species) and the Brevicyma clade (29 species). A key to the three species, distinguishing among them and separating them from the two species-rich Greater Antillean clades is provided.
\end{abstract}

Key Words: Miconia, Sagraea, Melastomataceae, Miconieae, Greater Antilles, Lesser Antilles

\section{RESUMEN}

Se investiga la sistemática de tres especies de Miconia sect. Sagraea de las Antillas Mayores, que también están en las Antillas menores y/o regiones continentales. Estos taxa, que representan linajes de dispersión probablemente independiente a las Antillas Mayores, se revisan taxonómicamente, incluyendo una descripción de cada una, información nomenclatural (incluyendo un nombre nuevo, Miconia sciaphila, y dos combinaciones nuevas, M. berteroi y M. septuplinervia), citas de especímenes, y una caracterización eco-geográfica. Estas especies se comparan con miembros de dos clados ricos en especies de la sect. Sagraea de diversificación independiente en las Antillas Mayores: el complejo Clidemia oligantha/C. leucandra (que comprende siete especies) y el clado Brevicyma (29 especies). Se aporta una clave de las tres especies, que las distingue y separa de los clados ricos en de especies- las Antillas Mayores.

During the course of recent investigations into the systematics and phylogeny of the tribe Miconieae (Melastomataceae) a number of taxonomic problems have come to light, and many of these relate to species of the Greater Antilles. Recent phylogenetic analyses (Bécquer et al. 2008; Goldenberg et al. 2008; Martin et al. 2008; Majure et al. 2014, 2015; Michelangeli et al. 2008, submitted) have shown nearly all of the genera of Miconieae to be highly polyphyletic, a result that is in keeping with the problematic generic delimitations within the tribe (Cogniaux 1891; Wurdack 1972, 1980; Ionta et al. 2012; Judd 1986, 1989; Judd \& Skean 1991; Judd et al. 2014a, b; Majure et al. 2015). Accordingly, major changes in generic circumscriptions within the tribe are required. The most workable solution to this classificatory problem (as clearly evident in figs. 1-3 of Goldenberg et al. 2008) is to place all species of Miconieae within a greatly expanded Miconia Ruiz \& Pav., comprising the DNA-supported clade within Miconieae that can be diagnosed by the synapomorphy of berry fruits (Gamba \& Almeda 2014; Goldenberg et al. 2013; Ionta et al. 2012; Judd et al. 2014a, b, 2015b; Majure et al. 2014, 2015). Additionally, the lack of megastyloids distinguishes Miconia from members of the Henriettieae 
(Penneys et al. 2010), and the presence of only one pair of bracteoles allows an easy separation from the species of Blakea (Penneys \& Judd 2011). Miconia is not the oldest generic name in the tribe, but it has been conserved against Leonicenia Scop. for over a century (Briquet 1906) and more recently a proposal to conserve it against the much smaller genera Tococa and Maieta (Michelangeli et al. 2016) was approved by the General Committee (Wilson 2017) and ratified by the Nomenclature Session of the International Botanical Congress in Chenzhen in 2016 (Turland et al. 2017).

Within Miconia sensu lato, major clades supported by recent and ongoing phylogenetic investigations have been recognized at infrageneric levels when morphologically diagnosable, e.g., sect. Calycodomatia Skean, Judd, Majure, \& Bécquer (Majure et al. 2015), sect. Calycopteris Judd, Bécquer, \& Majure (Judd et al. 2014a; Bécquer et al. 2017/18), sect. Chaenopleura (Rich. ex DC.) Hook. (Judd 2007; Judd et al. 2015a, 2017), sect. Echinatae Judd, Bécquer, \& Majure (Majure et al. 2015), sect. Krugiophytum (Cogn.) Majure \& Judd (Majure et al. 2014/15), sect. Lima Majure \& Judd (Majure \& Judd 2013; Majure et al. 2016), and sect. Miconiastrum (Bonpl. ex Naudin) Judd, Bécquer, \& Majure (Judd et al. 2014b), although some such clades have received only informal recognition, e.g., the Octopleura clade (Gambia \& Almeda 2014). The species of Miconia with axillary inflorescences, 4-merous flowers with well-developed external calyx lobes, and minute, shortstalked furrowed, gland-headed hairs represent one such clade: Miconia sect. Sagraea (DC.) Ionta, Judd, \& Skean (Ionta et al. 2012), the monophyly of which is supported by DNA sequence data (Goldenberg et al. 2008; Michelangeli et al. 2008, submitted; and Ionta, unpublished data). These plants traditionally have been treated as species of Clidemia D. Don or Ossaea DC. (see Cogniaux 1891; Moscoso 1943; Alain 1957; Michelangeli \& Becquer 2012; Proctor 1972; Fournet 1978; Howard 1989; Nicolson 1991; Axelrod 2011), although a few botanists have treated these species as the genus Sagraea (Judd 1989; Liogier 1995, 2000). As is typical for "genera" of Miconieae, however, both Clidemia and Ossaea have proven to be extremely non-monophyletic and morphologically undiagnosable. The distinctive short-stalked, glandular hairs of this clade, i.e., Sagraea-type hairs (see Ionta et al. 2012, fig. 1A; Wurdack1986, figs. 51, 52, 54-56), are likely synapomorphic, as are the axillary inflorescences, 4-merous flowers, and prominent external calyx teeth (Majure et al., unpublished data). Biogeographic and phylogenetic analyses support independent radiations of two major clades within sect. Sagraea in the Antilles (Goldenberg et al. 2008; Michelangeli et al. 2008, submitted)—a clade including 29 species, e.g , M. capillaris (Sw.) M. Gomez, M. portoricensis (Alain) Ionta, Judd, \& Skean, M. navifolia Ionta, Judd, \& Skean, M. scabrosa (L.) Ionta, Judd, \& Skean, M. scalpta (Vent.) Ionta, Judd, \& Skean, and M. woodsii (Judd \& Skean) Ionta, Judd, \& Skean, i.e., the Brevicyma clade of Cuba, Hispaniola, Jamaica and Puerto Rico, which is currently under revision by G. Ionta (see Ionta et al. 2012), and a clade including seven species of Cuba, Hispaniola, and Puerto Rico, i.e., the Clidemia oligantha (Urb.) Cogn./C. leucandra C. Wr. ex Griseb. complex, which is under revision by W.S. Judd (and collaborators; Judd et al. in prep.). Condensed inflorescences may be the only morphological synapomorphy of the Brevicyma clade, although the majority of these species also possess the additional apomorphy of sky-blue berries (and these species constitute a molecularly well-supported subclade, although such berries also are also characteristic of $M$. septuplinervia, indicating that bright blue fruits have evolved more than once). Morphological synapomorphies of the C. oligantha/C. leucandra clade remain unclear, but may include the usually distinctly pedicellate, but rather reduced few-flowered inflorescences typical for these species, and small flowers with recurved, oblong petals.

Phylogenetic analyses indicate that Miconia berteroi (DC.) Judd \& Ionta (=Clidemia plumosa (Desr.) DC.), M. sciaphila Judd \& Ionta (= Clidemia umbrosa (Sw.) DC.), and M. septuplinervia (Cogn.) Judd \& Ionta (= Clidemia septuplinervia Cogn.), although belonging within the Miconia sect. Sagraea clade, are not closely related to species of either the Brevicyma clade or the M. oligantha/M, leucandra complex (Michelangeli et al. 2008, submitted). Rather, they likely represent three independent introductions of Miconia sect. Sagraea into the Antilles from continental regions, as evidenced by the placement of these three species in earlier-diverging clades, among species native to continental regions of the Neotropics, and also by their broad distributionsoccurring in the Greater Antilles and additionally in the Lesser Antilles and/or continental regions. Of these three, Miconia sciaphila and M. berteroi are likely the more closely related, falling with a clade that also includes 
Clidemia monantha L. Wms., C. debilis Crueg., C. ampla Cogn., and Necranium gigantophyllum Britton (Michelangeli et al. submitted).

Miconia septuplinervia stands apart from both M. sciaphila and M. berteroi in its stems producing adventitious roots and often liana-like habit, in the lack of multicellular, simple, elongate, eglandular hairs on the stems, the nearly entire to only obscurely toothed leaves (vs. dentate to serrate margined leaves), the decurrent to long-decurrent (vs. obtuse to cordate) leaf bases, adaxial leaf surfaces often lacking elongate, simple, eglandular hairs (and when present these 0.1-0.4 mm long, vs. such hairs always present and 0.3-2.5 mm long), the inflorescences usually cauliflorous, forming basally branched, fasciculate cymes, and mature fruits bright, sky-blue (vs. blue- or purple-black) berries. Miconia sciaphila can be differentiated from the phenetically similar M. berteroi by its stems with multicellular, short to elongated, unbranched to usually poorly and distally branched hairs with bulging cells (in addition to Sagraea-type hairs and multicellular, simple, elongated, smooth-sided, eglandular hairs), the presence of pocket domatia on the abaxial leaf surface (at junction of major secondary veins with midvein, vs. domatia absent), bracteoles $1.2-2 \mathrm{~mm}$ long (vs. only $0.5-0.8 \mathrm{~mm}$ in $\mathrm{M}$. berteroi), calyx teeth $0.7-1.5 \mathrm{~mm}$ long (vs. 1.8-3.7 mm), and seeds with papillate cells (vs. obscurely to clearly bullate cells). In addition the hypanthia of M. sciaphila have sparse to moderate multicellular, simple, elongate, eglandular (or sometimes eglandular and gland-hairs) along with Sagraea-type hairs, these intergrading with branched and/or more elongate hairs with bullate cells, while the hypanthia of M. berteroi are densely covered by elongate, eglandular hairs, intermixed with Sagraea-type hairs, with elongated and bullate-celled hairs lacking. These three species are distinguished from the species of the Brevicyma clade and the M. oligantha/M. leucandra complex by the characters presented in the key below.

\section{MEASUREMENTS, TERMINOLOGY, METHODS, AND SPECIES CONCEPTS}

Nearly 300 specimens of Miconia berteroi, M. sciaphila, and M. septuplinervia were examined for this study. Most were from the Antilles, but specimens from outside the Antilles were also examined. The first author has collected M. berteroi and M. sciaphila, while the second author has collected M. berteroi (see specimens examined). Herbaria from which specimens were studied are listed in the Acknowledgments. Abbreviations follow Thiers (accessed 2018, [continuously updated]). One hundred and eighty-one different characteristics were measured or observed for each species.

All measurements included in the key and descriptions of species were taken directly from dried material, with the exception of plant height and flower/fruit color, which are based on information from specimen labels, observed in the field, or from photographs, and floral measurements, which were made from rehydrated material. Measurement of floral parts follows Judd (2007), Judd et al. (2014a, b), along with guidelines for contributors to the on-line monograph of Miconieae (Michelangeli et al. 2009 onward). The outgrowths of the abaxial surface of the calyx lobes are here termed calyx teeth (following Judd et al. 2014a, b), rather than "external calyx lobes," as in Judd (2007); the sterile extension of the ovary apex surrounding the base of the style is termed a collar, while a ring of hairs atop the ovary is termed a crown. The inflorescence axis immediately below the pair of bracteoles subtending a flower is termed the pseudopedicel, and the axis above the bracteole pair, distancing the bracteoles from the flower, itself, is the pedicel. Finally, species descriptions follow the format of the on-line monograph of Miconieae (Michelangeli et al. 2009 onward).

Species delimitations are based on the morphological-phenetic species concept (Judd 2007) and the diagnostic species concept (Wheeler \& Platnick 2000; see also Judd \& Ionta 2013).

\section{TAXONOMIC TREATMENT AND KEY TO THE SPECIES OR MAJOR-CLADES OF MICONIA SECT. SAGRAEA IN THE GREATER ANTILLES}

1. Plant producing adventitious roots on stems; inflorescences usually on much older stems, below the leaves Miconia septuplinervia

1. Plant with the stems lacking adventitious roots; inflorescences in the leaf axils or on slightly older branches. 
3. Stems with multicellular, slender, unbranched to distally few-branched hairs with \pm bullate cells (in addition to elongate, simple, smooth-sided, eglandular hairs and Sagraea-type hairs, i.e., short-stalked glandular hairs with furrows between the cells of the head)

Miconia sciaphila

3. Stems not as above, i.e., with various hair types, but without hairs with bullate cells.

4. Stems with elongate hairs with few to numerous, sharply pointed, side branches

Brevicyma clade

(M. scabrosa and relatives)

4. Stems with elongate, unbranched, eglandular or gland-headed hairs; or elongated hairs absent.

5. Ovary crown of closely adjacent, thick, finger-like hairs; petals yellow; calyx teeth $3.5-5 \mathrm{~mm}$ long

Clidemia

rubripila Cogn.

5. Ovary crown of scattered, slender hairs or crown absent; petal pale green to white; calyx teeth $0.3-3.7 \mathrm{~mm}$ long.

6. Calyx teeth $0.3-2.3 \mathrm{~mm}$ long; the hypanthium with elongate, eglandular hairs $2-4 \mathrm{~mm}$ long (and also with Sagraea-type hairs)

Miconia berteroi

6. Calyx teeth 1.8-3.7 mm long; the hypanthium with elongate, eglandular and/or gland-headed hairs 0.3-1 $\mathrm{mm}$ long, or such hairs absent (and with variously modified Sagraea-type hairs) C. oligantha/C. leucandra complex

1. Miconia berteroi (DC.) Judd \& Ionta, comb. nov. (Fig. 1). Sagraea berteroi DC., Prodr. 3:171. 1828. Clidemia berteroi (DC.) Griseb., Fl. Brit. W.I. 247. 1860. TYPe: JAMAICA: without definite locality, C.L.G. Bertero s.n. (ноLотYPE: G-DC [G-DC 00310852] digital image!; PHOTO OF HOLOTYPE at G-DC, F!, GH!).

Melastoma plumosum Desr. in J.B.A.P.M. de Lamarck, Encycl. 4:31. 1797. Clidemia plumosa (Desr.) DC., Prodr. 3:159. 1828. Sagraea plumosa (Desr.) Naudin, Ann. Sci. Nat. Bot., sér. 3, 18:93. 1852. Type: ST. DOMINGUE [= HAITI]: without definite locality (HOLоTYPE: P-JU; рното of SPECimen At P: F!, MO!). Non Miconia plumosa Gleason, Bull. Torrey Bot. Club 52:381. 1925; non M. plumosa Markgr., Notizbl. Bot. Gart. Berlin-Dahlem 10:54. 1927.

Shrub to 3.5(-4) m. Indumentum of minute, multicellular, short-stalked, gland-headed hairs that have furrows between the cells of the head (i.e., Sagraea-type hairs), and cream-colored to red, multicellular, simple, elongate, [eglandular or gland-headed] hairs. Young stems terete to elliptic (in cross-section), with dense, multicellular, simple, elongate, spreading, straight to flexuous, eglandular hairs, these $1-2.5 \mathrm{~mm}$ long, mixed with scattered Sagraea-type hairs, both \pm persistent, and hairs of the nodes similar to those of internodal regions; internodes 4-14 cm long, the nodes slightly swollen or not, without nodal line. Leaves only slightly anisophyllous (occasionally strongly so, i.e., smaller leaf only ca. $1 / 4$ size of larger one); petiole $0.7-10 \mathrm{~cm}$ long, \pm terete with a dorsal groove, the indumentum moderate to dense, elongate, spreading, eglandular hairs and scattered Sagraea-type hairs; blade (3.7-)6.5-32 cm long, (1.5-)2.4-16.3 cm wide, ovate, \pm flat, chartaceous, the apex acuminate to attenuate, the base obtuse to cordate, the margin plane, irregularly dentate to serrate-dentate, the largest teeth to $0.3-1.5 \mathrm{~mm}$, and with eglandular hairs associated with teeth and margin, their length to $1-2$ $\mathrm{mm}$; venation acrodromous, with prominent midvein and 3 (or occasionally only 2 ) secondary vein pairs, \pm basal, the outermost pair inframarginal and inconspicuous, positioned 0.5-2 $\mathrm{mm}$ from margin (or ending below widest point of blade), the inner 2 (or occasionally only 1) pair(s) conspicuous, positioned (2-)5-41 mm and 1.5-9 mm from margin, respectively, the tertiary veins numerous, percurrent, oriented subperpendicular to midvein and 1.3-10 mm apart, joined by numerous percurrent quaternary veins, and the higher order veins orthogonal-reticulate; adaxial surface green, the midvein with elongate, eglandular hairs and Sagraea-type hairs, the other veins with Sagraea-type hairs, and lamina with dense to moderate, straight to flexuous, elongate, eglandular hairs, these 0.3-2.5 mm long, along with scattered Sagraea-type hairs, both persistent, the midvein impressed, the other veins very slightly impressed to flat; abaxial surface pale green, with midvein to higher order veins with dense to moderate, elongate, straight to sinuous, eglandular hairs (similar to those of the adaxial surface) and scattered Sagraea-type hairs, the midvein and major secondary veins strongly to moderately raised, the tertiary, quaternary, and minor secondary veins slightly raised, and the higher-order veins flat or very slightly raised; domatia absent. Inflorescences axillary (and usually among the leaves, but rarely also on slightly older nodes below leaves), 5-ca. 60-flowered, open cymes with basalmost node often with several axillary branches, with 1-3 major branch-pairs/clusters, with 1 or occasionally 2 inflorescences per leaf axil, 2-11 cm long, 1-8 cm in diameter, proximal segment of lowermost inflorescence branches 2-21 mm long, the ultimate axes (pseudopedicels) $0.5-4 \mathrm{~mm}$ long, and flowers \pm well-spaced, the inflorescence branches with dense, multicellular, simple, elongate, eglandular hairs and scattered Sagraea-type hairs; peduncle $0.8-5.6 \mathrm{~cm}$ 


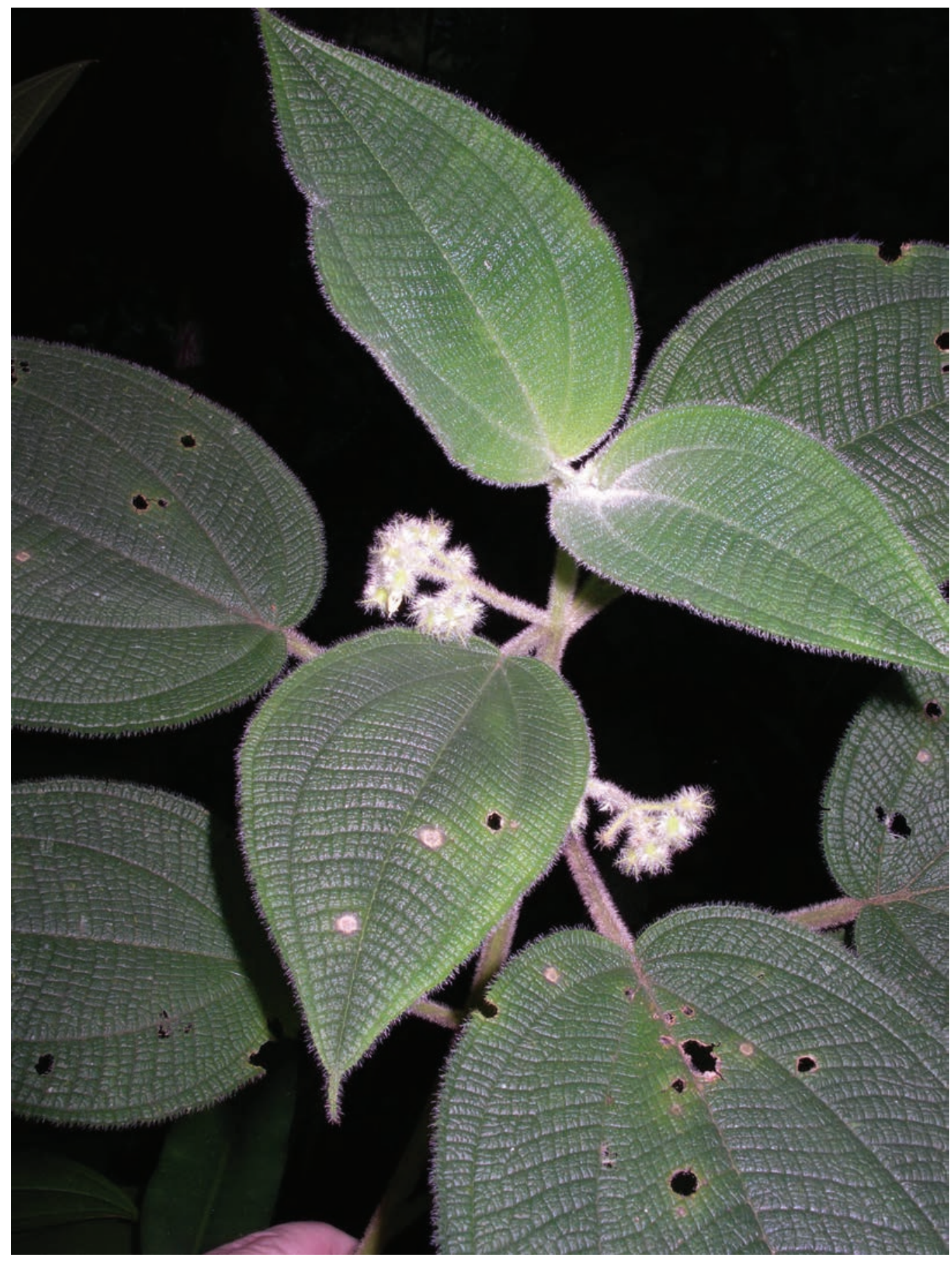

FIG. 1. Miconia berteroi branch with axillary inflorescences (Ionta et al. 2003). 
long, with indumentum of dense, elongate, eglandular hairs and scattered Sagraea-type hairs; bracts 0.8-3 $\times$ 0.2-0.35 mm, narrowly triangular, with acute apex, persistent or deciduous, with elongate, eglandular hairs and Sagraea-type hairs; bracteoles $0.5-0.8 \times 0.1-0.2 \mathrm{~mm}$, narrowly triangular to linear, with acute apex, \pm persistent, with elongate, eglandular hairs and Sagraea-type hairs. Flowers 4-merous, radial, with pedicel 0.5-3 mm long. Hypanthium 2.3-3.1 mm long, \pm cylindric, sometimes slightly flaring, not constricted, the free portion 1.1-1.4 mm long, 1.5-1.9 mm wide at the base of the calyx, the outer surface with dense multicellular, simple, elongate, eglandular hairs and scattered Sagraea-type hairs, the inner surface \pm smooth, with scattered Sagraea-type hairs, androecial fringe absent. Calyx lobes 4, separate in bud, $0.2-0.5 \times 0.7-0.9 \mathrm{~mm}, \pm$ broadly triangular, the apex rounded to obtuse, the margins entire, abaxially with elongate, eglandular hairs and Sagraea-type hairs, and adaxially with a few Sagraea-type hairs; calyx tube $0.15-0.25 \mathrm{~mm}$ long, not tearing between lobes, with a few Sagraea-type hairs on adaxial surface. Calyx teeth present, 4, 1.8-3.7 mm long, borne dorsally near base of calyx lobes, erect-spreading, with acute apex, and dense, elongate, eglandular hairs and scattered Sagraea-type hairs. Petals 4, translucent pale green or white, 1.6-3 × 1-1.4 mm, elliptic to oblong or slightly obovate, spreading to recurved at anthesis, the adaxial surface glabrous, the abaxial surface glabrous, the apex rounded and with a small apical notch, the base slightly narrowed, the margin entire. Stamens 8 , nearly isomorphic (i.e., differing slightly in anther length), geniculate near apex of filament, \pm radial; staminal filament 1.3-2.5 mm long, flattened-terete, glabrous, white to pale green; anther thecae 1.3-2.4 × 0.2-0.4 $\mathrm{mm}$, narrowly ovoid, yellow, opening by a small apical pore, the connective slightly thickened and basally extended, unappendaged. Ovary 4-locular, $1.9-2.5 \mathrm{~mm}$ long, 1.3-2.5 mm wide, ca. $2 / 3$ to 3/4-inferior, with a cylindrical apical collar surrounding the style, the collar ridged and apically lobed, and without a crown, the ovary apex glabrous or with a few Sagraea-type hairs, with axile placentation, the ovules numerous, borne on expanded placenta; style 5.4-6.5 mm long, straight, terete, white, glabrous; stigma truncate to slightly capitate, 0.3-0.4 mm wide. Berries 5-9 mm long, 4-7.5 mm in diameter, globose to ellipsoid, dark blue at maturity, with moderate, elongate, eglandular hairs and Sagraea-type hairs. Seeds 0.3-0.4 mm long, hemispheric-obovoid, with elliptic, flat, hilum, covering ca. $4 / 5$ of length of seed; testa with clearly to only slightly bullate cells; appendage absent.

Phenology.-Recorded in flower in every month of the year.

Distribution and habitat.-Within the Antilles Miconia berteroi is restricted to Hispaniola (Haiti and the Dominican Republic; Fig. 2), where it occurs in the Massif du Nord/Cordillera Central, and to Jamaica (Fig. 3), where it occurs in the eastern Blue Mountains and the John Crow Mountains. In the Antilles the species grows in cloud forests, moist montane forests and thickets, frequently over limestone, from 300-1250 m. The species also occurs in South America (Venezuela).

Additional specimens examined. DOMINICAN REPUBLIC. Prov. Santiago: Municipio San José de las Matas, paraje Los Calimetes, en las márgenes o proximidades del río El Gallo, 1125 m, 16 Jun 1999, Clase \& Peguero 1320 (FLAS, JBSD, MO); La Cidra, 640 m, 7 Apr 1955 , Gonzalez et al. 2911 (UCMM, US); San José de las Matas, Loma Bajita, 700-800 m, 25 May 1933, Valeur 875 (F, GH, MO, NY, US, S). Prov. Santiago Rodriguez: Cordillera Central, Municipio San Ignacio de Sabaneta, La Cidra, sección el Copey, ca. 5 km después de la caseta de guarda parques, subiendo hacia Sierra Mocha, UTM 252960E, 2127153N, 1240 m, 15 Feb 2011, Clase \& Bachmann 6589 (FLAS); Cordillera Central, en el poblado rural "Las Lagunas de Cenoví" ca. 3.6 hr. por mulo al Sur de El Aguacate (de Monción), en las laderas del Arroyo Caña, $19^{\circ} 15^{\prime} \mathrm{N}, 71^{\circ} 18^{\prime} \mathrm{W}, 1050-1100$ m, 29 Nov 1989, Zanoni et al 43745 (FLAS, JBSD, MO, S). HAITI. Dept. du Nord: Poste Marie Congo, 1000 m, Jun 1901, Buch 749 (IJ); Massif du Nord, Port Margot, Morne Maleuvre, on the spur towards Le Limbé, 900 m, 8 Dec 1924, Ekman H2835 (A, IJ, S, US); Petit Borgne to Mt. Casse, ca. 3000 ft, 16 Aug 1903, Nash 527 (NY); Massif du Nord, 12.5 km al "este" de Anse-a-Foleur y en la carretera a Petit Bourg de La Borgne y Le Borgne, 1955'N, 72³5'W, 570 m, 7 Jun 1986, Zanoni et al 34944 (FLAS, JBSD, NY, S). Dept. du Nord Ouest: Massif du Nord, Port-de-Paix, Haut Piton, 800-1000 m, 6 Apr 1925, Ekman H3689 (NY, S); vicinity of Port de Paix, La Coup Rd, 22 Jan 1929, Leonard \& Leonard 12313 (GH, NY, US); rd from Camp No. 1 to La Barrière Couchant, $2500 \mathrm{ft}, 17$ Jul 1905, Nash \& Taylor 1050 (NY). JAMAICA. Portland Parish: Joe Hill, near Port Antonio, 2000 ft, 13 Jul 1965, Barkley \& Proctor 35135 (IJ); Swift River, 1000 ft, 20 Oct 1983, Bretting J-292 (IJ); wooded slope above Mabess River, 3000 ft, 21 Dec 1905, Harris 9127 (F, NY, US); John Crow Mountains, 1700 ft, 10 Mar 1909, Harris \& Britton 10762 (F, NY, US); John Crow Mountains, S of Ecclesdown by rd, then hiked W across Driver River and followed trail toward Big Flat, 1801'11.9" N, 76¹9'3.5"W, 386-430 m, 20 Jan 2011, Ionta et al. 2003 (FLAS, NY); Stony River Base Camp, ca. $1250 \mathrm{ft}$, 15 Dec 1973, Morley \& Whitefoord 514 (A, MO, US); Blue Mountains, Nanny Town to Kill Dead, near Stony River, 2600 ft, 22 Dec 1973, Morley \& Whitefoord 735 (A, IJ, MO, US); Mabess River, 2500 ft, 25 Jul 1903, Nichols 156 (NY); valley of the Stony River, near Nanny Town, ca. 1800 ft, 23 Jul 1967, Osmaston 5102 (IJ); Blue Mountains, spring near Trafalgar, 5 May 1916, Perkins 1129 (F, GH); 1-1.5 mi SW of 


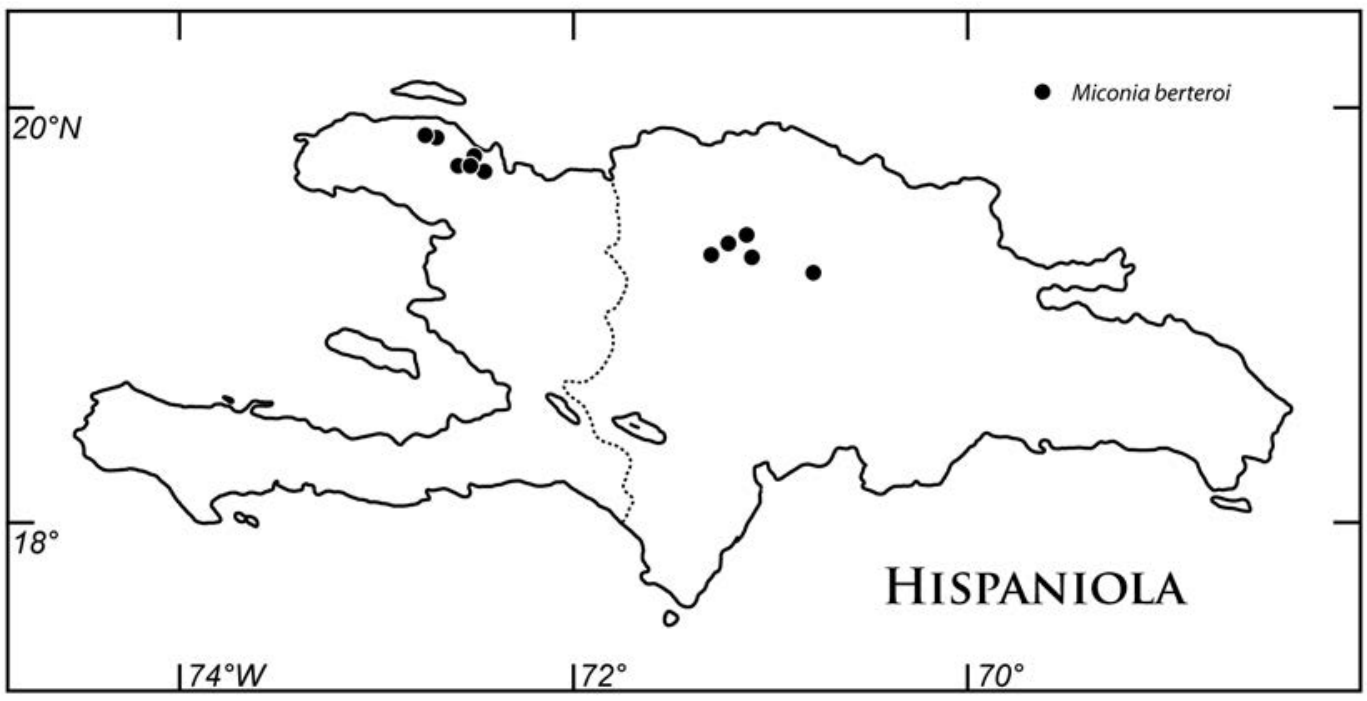

FIG. 2. Distribution of Miconia berteroi on Hispaniola.

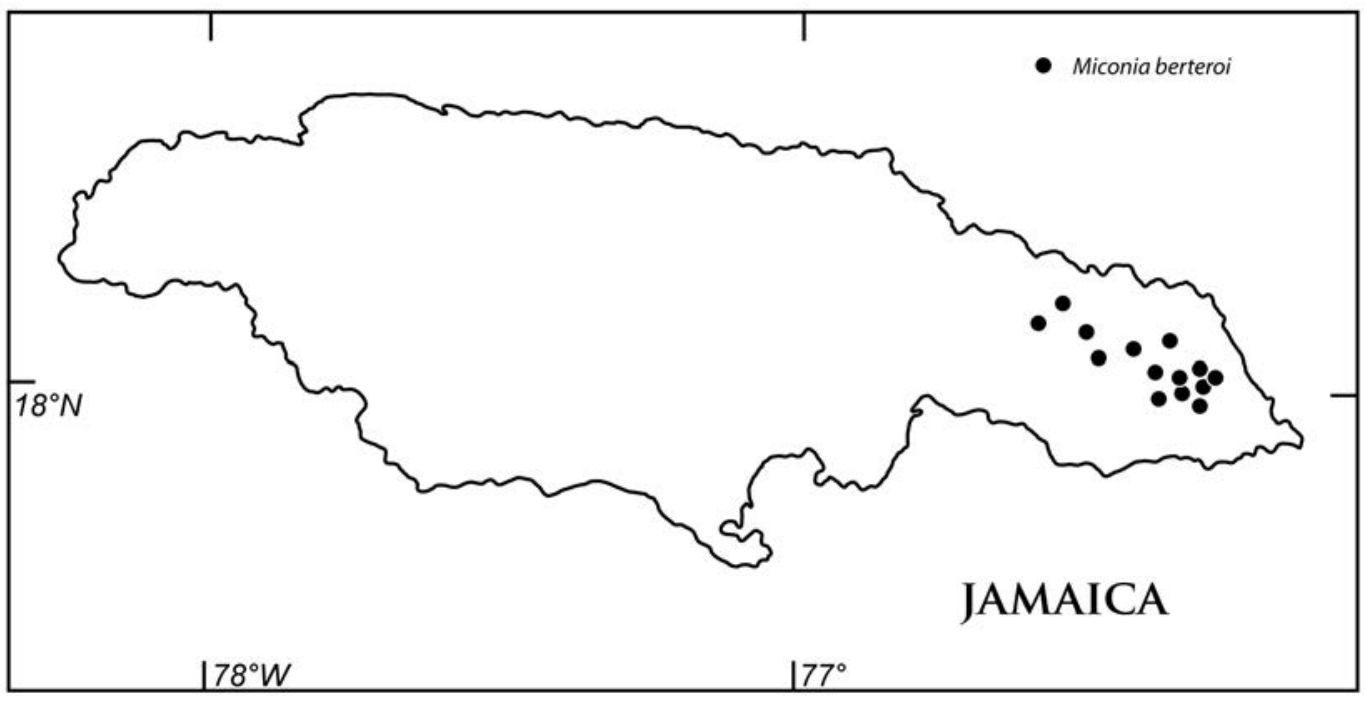

FIG. 3. Distribution of Miconia berteroi in Jamaica.

Ecclesdown, E slope of John Crow Mountains, 1000-1500ft, 9 Apr 1954, Proctor 8599 (GH, IJ); NW slope of Joe Hill, 1000-2250ft, 20 Apr 1955, Proctor 10086 (IJ, NY); E slope of John Crow Mountains, 1.5-2 mi SW of Ecclesdown, 1500-2000 ft, 4 Apr 1963, Proctor 23429 (IJ, MICH, NY, US); gorge of the Stony River, above jct of the Macungo River, 1300-1500 ft, 25 Jul 1967, Proctor 28357 (IJ); St. Georges, Aug 1843 , Purdie s.n. (NY); John Crow Mountains, E slope of John Mody Mt., E of Ecclesdown, from Foster property (ca. 1 km N of town) ca. 3 hours walk on logging rd that ascends mountain, 22-24 Jun 1992, Salzman et al 118 (FLAS, IJ, US); John Crow Mountains, E slope, ca. 1.5 mi SW of Ecclesdown, 1000-1500 ft, 9 Aug 1964, Webster \& Wilson 5157 (A, IJ, MICH, US); Joe Hill, 1-1.5 mi SE of Windsor, 1500-2000 ft, 13 Jul 1965, Webster \& Barkley 13738 (IJ). St. Thomas Parish: Corn Puss Gap, 2100 ft, 25 Apr 1946, Barry s.n. (IJ); along small stream above and W of Bowden Pen, ca. 1250 ft, 3 Aug 1963, Crosby \& Anderson 1074 (F, GH, MICH, MSC); between Mansfield and Devil's River, 16 Sep 1908 , 
Harris \& N.L. Britton 10572 (F, NY); E end of the Blue Mountains, near jct. with John Crow Mountains, NE of Hayfield, hiking along the Cuna-Cuna trail, 1759'24.7"N, 76²2'52.7"W, 682-700 m, 22 Jan 2011, Ionta $\varepsilon$ Judd 2007 (FLAS); Corn Puss Gap, 2000 ft, 27 May 1949 , Lewis s.n. (IJ); Mansfield, near Bath, 2 May 1903, Maxon 1810 (US); crest of Gossamer Peak, 800-900 m, 16 Jun 1926, Maxon 9302 (NY, US); along the Wild Cane River, 1.1 mi SE of Macungo Hill, ca. 1500 ft, 14 May 1968, Proctor 28718 (FLAS, IJ); Corn Puss Gap, ca. 2000 ft, 15 Jan 1971, Proctor 31584 (F, IJ, MO, US); Blue Mountains, 1-2 mi SE of Cuna Pass, 2500-2700ft, 26 Aug 1954, Wilson \& Murray 633 (A, IJ, US); John Crow Mountains, Corn Puss Gap, 2000 ft, 25 Jan 1958, Yuncker 18113 (F, MICH, NY, S).

The Antillean populations of Miconia berteroi are not morphologically differentiable from those of South America (e.g., Liesner \& González 9713, Liesner \& Medina 13585, Liesner \& Steyermark 12365, Seres 272, Steyermark 106710, all at NY). The species is easily distinguished from the phenetically similar M. sciaphila by the absence of elongated, simple to poorly branched hairs with bulging cells, the absence of pocket domatia (at junction of major secondary veins with midvein) on the abaxial surface of the lamina, bracteoles $0.5-0.8 \mathrm{~mm}$ long (vs. 1.2-2 mm long), calyx teeth 1.8-3.7 mm long (vs. 0.7-1.5 mm), and seeds with obscurely to clearly bullate cells (vs. papillate cells). In addition, the hypanthia of $M$. berteroi have very dense elongated, eglandular hairs, intermixed with Sagraea-type hairs, while the hypanthia of M. sciaphila have sparse to moderate multicellular, simple, elongate, eglandular hairs (or sometimes eglandular and gland-hairs) along with Sagraea-type hairs, these intergrading with branched and/or more elongate hairs with bullate cells.

The chromosome number of $n=17$ has been reported for this species, based on a collection (Wurdack 2680) from Venezuela (Solt \& Wurdack 1980). This number is not surprising, as it is the most commonly reported number for the tribe.

The epithet "plumosa," unfortunately, is occupied in Miconia, so the synonym Clidemia berteroi must be taken up when the species is transferred to Miconia. An unpublished illustration of Miconia berteroi (as Melastoma plumosum) is at BM (\#000593940) and this is based on a specimen collected in Jamaica (i.e., without definite locality, Sloan s.n., BM 00593941, viewable on JSTOR Global Plants).

2. Miconia sciaphila Judd \& Ionta, nom. nov. (Fig. 1) Melastoma umbrosum Sw., Prodr. 72. 1788. Sagraea umbrosa (Sw.) DC., Prodr. 3:171. 1828. Staphidiastrum umbrosum (Sw.) Naudin, Ann. Sci. Nat. Bot., sér. 3, 17:327. 1852. Clidemia umbrosa (Sw.) Cogn. in J.B.A.M.P. de Candolle \& A.C.P. de Candolle, Monogr, Phan. 7:1019. 1891. TYpe: SAINT KITTS AND NEVIS: St. Christopher [= Saint Kitts], S. Fahlberg s.n. (LECTOTYPE: BM, ISOLECTOTYPE: S [S R-3487] digital image!, possible ISOLECTOTYPE, S [S 11-16909] digital image!). Non Miconia umbrosa Cogn. in von Martius, Fl. Bras. 14(4):315. 1887.

Melastoma latifolium Desr. in Lamarck, Encycl. 4:31. 1797. Clidemia latifolia (Desr.) DC., Prodr. 3:159. 1828. Staphidiastrum latifolium (Desr.) Naudin, Ann. Sci. Nat. Bot., sér. 3, 17:326. 1852. Staphidium latifolium (Desr.) Griseb., Abh. Königl. Ges. Wiss. Gottingen 7:218. 1857. Sagraea latifolia (Desr.) Triana, Trans. Linn. Soc. London 28:138. 1871. TYPE: MARTINIQUE: J. Martin s.n. (HOLOTYPE: P-JU; рното оғ ноLотүPE: F!, MO!). Non Miconia latifolia Naudin, Ann. Sci. Nat., Bot. sér. 3, 16:244. 1851.

Shrub or small tree, to $6 \mathrm{~m}$. Indumentum of minute, \pm cream-colored, multicellular, short-stalked, glandheaded hairs that have furrows between the cells of the head (i.e., Sagraea-type hairs), and multicellular, simple, erect, elongate, \pm erect, stout and smooth-sided, \pm cream-colored, eglandular hairs, and shorter, erect to appressed multicellular hairs, these simple to poorly and shortly branched distally, with \pm bulging and/or roughened cells, and intergrading with the Sagraea-type hairs. Young stems quadrangular to \pm terete, with (rarely sparse) moderate to dense, multicellular, simple, elongate, erect, stout and smooth-sided, straight to slightly flexuous, eglandular hairs, these 1.5-6 mm long, mixed with dense Sagraea-type hairs, sometimes with a few non-glandular branches, these hairs intergrading with dense, slender, more elongated, and unbranched to distally poorly and shortly branched hairs with \pm bulging cells, these to $1.5 \mathrm{~mm}$ long and appressed, all hair types \pm persistent, and hairs of the nodes similar to those of the internodes or internodes with bullate-celled hairs more elongated (or rarely, i.e., in the "latifolia" entity, the Sagraea-type hairs with more numerous non-glandular branches, so globular-stellate, and these sometimes elongated, with numerous, conspicuous branches); internodes $2-12.5 \mathrm{~cm}$ long, the nodes slightly swollen, with a nodal line. Leaves slightly anisophyllous; petiole $1.2-18 \mathrm{~cm}$ long, terete and distally grooved, the indumentum of moderate to dense elongate, erect, stout and smooth-sided, eglandular hairs, moderate Sagraea-type hairs and these intergrading with slender multicellular hairs with \pm bulging cells; blade $7.5-37 \mathrm{~cm}$ long, $3.5-26.5 \mathrm{~cm}$ wide, ovate to nearly elliptic, often very broadly so, \pm flat, chartaceous, the apex acuminate, the base (rarely acute) obtuse to 
slightly cordate, the margin plane, obscurely to clearly dentate or dentate-serrate, the largest teeth to $0.2-1$ $\mathrm{mm}$, and with the tooth apex and margin with elongate, eglandular hairs to 1-2 mm long; venation acrodromous, with prominent midvein and 3 secondary vein pairs, \pm basal, the outermost 1 pair intramarginal and inconspicuous, positioned $0.4-3.5 \mathrm{~mm}$ from margin, the inner 2 pairs conspicuous, positioned $7-57 \mathrm{~mm}$ and $1.5-14.5 \mathrm{~mm}$ from margin, respectively, the tertiary veins numerous, percurrent, oriented subperpendicular to midvein and 1.7-10.5 mm apart, joined by numerous percurrent quaternary veins, and the higher order veins orthogonal-reticulate; adaxial surface green, the midvein and prominent secondary veins with dense, slender hairs with \pm bulging cells, these unbranched or shortly and poorly branched distally, and intergrading with Sagraea-type hairs (and elongate, smooth-sided hairs lacking), the other veins with only Sagraea-type hairs (but these may be few-branched and/or slightly elongated), and lamina with moderate, elongate, smoothsided, eglandular hairs, these $0.3-2.2 \mathrm{~mm}$ long, along with scattered Sagraea-type hairs (but some of these with a few non-glandular branches), both \pm persistent, the midvein impressed, the secondary veins slightly impressed, other veins very slightly impressed to flat; abaxial surface pale green, with midvein to fifth-order veins with dense to scattered elongate, simple, smooth-sided, eglandular hairs, these straight to slightly sinuous (and similar to those of the adaxial lamina), and scattered Sagraea-type hairs (and rarely, i.e., in the "latifolia" entity, these often with numerous non-glandular branches), the midvein and major secondary veins moderately to strongly raised, the tertiary, quaternary, and minor secondary veins slightly raised, and higherorder veins flat to very slightly raised; domatia usually present, pocket-like, at junction of major secondary veins and midvein. Inflorescences axillary, in leaf axils or at old nodes, just below leaves, 5-ca. 30-flowered, open cymes, with 1-4 major branch-pairs, with 1 or 2 (rarely 3) inflorescences per leaf axil, 3-13.5 cm long, $1-15 \mathrm{~cm}$ in diameter, proximal segment of lowermost inflorescence branches to $4.5-40 \mathrm{~mm}$ long, the ultimate axes (pseudopedicels) 1-16 mm long, and flowers well separated, the inflorescence branches with sparse to moderate, multicellular, simple, elongate, gland-headed and eglandular hairs or sometimes only eglandular hairs, along with Sagraea-type hairs, these intergrading with more elongated, simple to poorly branched hairs with bulging cells (and in the "latifolia" entity with Sagraea-type hairs often having several nonglandular branches, i.e., becoming globular-stellate); peduncle $0.8-4.5 \mathrm{~cm}$ long, with indumentum similar to that of the inflorescence branches; bracts $1.2-4.5 \times 0.3-1.2 \mathrm{~mm}$, obovate or spathulate, linear, or narrowly triangular, with acute to acuminate apex (but rarely becoming leaflike, i.e., to $40 \mathrm{~mm}$ long and $10 \mathrm{~mm}$ wide, and ovate), persistent, with elongate, eglandular hairs and Sagraea-type hairs, these sometimes with a few nonglandular branches or elongated with bulging cells; bracteoles 1.2-2 $\times 0.3-1.3 \mathrm{~mm}$, obovate or spathulate, linear, or narrowly triangular, with acute to acuminate apex, persistent, with elongate, eglandular hairs and Sagraea-type hairs, these sometimes with a few nonglandular branches or elongated with bulging cells. Flowers 4-merous, radial, with pedicel 0-1.5 mm long. Hypanthium 1.9-2.4 mm long, \pm cylindric, not flaring, not constricted, the free portion 1-1.3 mm long, 1.2-1.5 mm wide at the base of the calyx, the outer surface with sparse to moderate, multicellular, simple, elongate, eglandular hairs or with a mixture of eglandular and gland-headed hairs, and Sagraea-type hairs, these sometimes with few basal, non-glandular branches or somewhat elongated, simple or sparsely branched and with \pm bulging cells (and in the "latifolia" entity also with globular-stellate hairs), the inner surface \pm smooth, glabrous or with few elongated hairs, especially near apex, androecial fringe absent. Calyx lobes 4, separate in bud, $0.25-0.6 \times 0.9-1.4 \mathrm{~mm}, \pm$ triangular, the apex rounded to obtuse, the margins entire, abaxially with elongate, eglandular hairs or a both eglandular and gland-headed hairs, along with Sagraea-type hairs, these often few-branched and/or elongated (and in "latifolia" entity also with much branched hairs) and adaxially with a few Sagraea-type hairs; calyx tube $0.2-0.35 \mathrm{~mm}$ long, not tearing between lobes, with few Sagraea-type hairs on adaxial surface. Calyx teeth present, 4, 0.7-1.5 mm long, borne dorsally on calyx lobes, \pm erect to spreading, with acute apex, and elongate eglandular or eglandular and glandheaded hairs, along with Sagraea-type hairs, these often with a few non-glandular branches and/or slightly elongated. Petals 4 , white to pale green, $1.3-2 \times 0.9-1.7 \mathrm{~mm}$, oblong, or broadly ovate or elliptic to slightly obovate, spreading to recurved at anthesis, the adaxial surface glabrous, the abaxial surface glabrous, the apex rounded, often slightly notched, the base slightly narrowed or broad and parallel-sided, the margin entire. 
Stamens 8, isomorphic, geniculate near apex of filament, \pm radially arranged; staminal filament 1.3-2.2 mm long, flattened-terete, glabrous, white; anther thecae $1.3-2 \times 0.3-0.4 \mathrm{~mm}$, ovate to oblong-linear, cream to white, opening by single apical pore, the connective slightly enlarged and basally extended, not appendaged. Ovary 4-locular, $1.7-1.9 \mathrm{~mm}$ long, $1.5-2 \mathrm{~mm}$ wide, $2 / 3$ to $3 / 4$-inferior, with a cylindrical apical collar surrounding the style, the collar slightly lobed, and without a crown although ovary with a few small, glandular hairs, especially on the collar, with axile placentation, the ovules numerous, borne on expanded placenta; style 3-5 mm long, straight, terete, white, glabrous; stigma capitate, $0.45-0.8 \mathrm{~mm}$ wide. Berries $4-11 \mathrm{~mm}$ long, 3.5-10 mm in diameter (expanding greatly just before maturity), \pm globose, purple when immature and turning purpleblack, blue-black or dark blue at maturity, with sparse to moderate, elongate, eglandular hairs and Sagraeatype hairs. Seeds $0.3-0.35 \mathrm{~mm}$ long, hemispheric-obovoid, with elliptic, flat, hilum covering $3 / 4$ to $4 / 5$ of length of seed; testa cells \pm papillate; appendage absent.

Phenology.--Recorded in flower in every month of the year.

Distribution and habitat.-Miconia sciaphila occurs in Puerto Rico (Luquillo Mountains) and southward through the Lesser Antilles (Dominica, Guadeloupe, Martinique, Netherlands Antilles-Saba, Montserrat, Saint Kitts and Nevis, and Saint Lucia), where it grows in rainforests and moist montane forests (often along streams) from 150-880 m (Fig. 4). The species may also occur in Trinidad, but its occurrence there is based on a single old collection (without definite locality).

Additional specimens examined. PUERTO RICO: Caribbean National Forest, El Yunque Recreation Area, $18^{\circ} 17^{\prime} \mathrm{N}, 65^{\circ} 47^{\prime} \mathrm{W}, \mathrm{ca} .600 \mathrm{~m}, 4$ Aug 1986, Boom 6813 (F, MO, NY); Sierra de Luquillo, 26 Apr 1982, Jiménez et al. s.n. (UCMM); Luquillo National Forest, La Coco falls, along Rt. 191, 500 m, 13 Jun 1991, Judd \& Judd 6022 (FLAS); Río Blanco Arriba, 800 m, 10 Aug 1982, Liogier et al. 33351 (MO, NY); Luquillo Mts., Luquillo Experimental Forest, Rt. 191, Km 9.8, 1500 ft, 17 Jul 1966, Little 21627 (US); Sierra de Luquillo, Caribbean National Forest, Barrio Sabana, mountain slopes E of Río Mameyes, 250-300 m, 6 Apr 1988, Proctor 44643 (US); ibid., Rd 988 at Vereda Angelito, ca. 150 m, 14 May 1996, Proctor \& Skean 30690 (US); Sierra de Luquillo, Caribbean National Forest, along Rt 988 where the Vereda Angelito trail begins, 18¹9'46"N, 654'83"W, 14 May 1996, Skean \& Proctor 3726 (MICH); Sierra de Luquillo, Caribbean National Forest, along Rt. 191 at km 9.8, Quebrada Juan Diego, W side of rd, just N of river, 480 m, 11 Jun 1997, Skean $\&$ Jones 3796 (FLAS); S side of Luquillo Mts, at Km 19.5 on Rt. 191, 14 Jan 1967, Wagner 1084 (A, MO); Luquillo Mts, Rd. 191, Km 9.6, 15 Oct 1972, Woodbury 22466 (NY, US); Luquillo Mts, El Yunque, Coco Falls, 17 Jun 1962, Woodbury s.n. (NY); Rd. 191, Km 19.6, 15 Oct 1972, Woodbury s.n. (NY). Lesser Antilles. DOMINICA: Sylvania Estate, 21 Jan 1933, Cooper 27 (F, NY, US); ibid., Cooper 27A (F, MICH, NY, US); Morne Gombo, 29 Feb 1880, Eggers 99 (GH); ibid., 700 m, Oct 1887, Eggers 529 (GH); Fond Figues River near bridge on rd to Castle Bruce from Pont Cassé, ca. 400 ft, 6 Apr 1964, Ernst 1017 (GH, US); between Point Lolo and Pont Cassé, NW of Morne Trois Pitons, 1400-1600ft, Ernst 1284 (US); Lisdara Estate, near Belle View, Aug 1937, Hodge 518 (GH); Sylvania, slopes of Morne Colla Anglais, 610-732 m, 10-23 Aug 1938, Hodge 519 (GH, NY, US); Lisdara Estate, near Belle View, Aug 1937, Hodge 1010 (GH); South Chiltern Estate, 500 m, 27-28 Feb 1940, Hodge \& Hodge 1481 (GH); between Laudat and Freshwater Lake, 665 m, 8-9 Mar 1940, Hodge \& Hodge 1756 (GH); Providence Valley, just W of Laudat, 500 m, 13 Mar 1940, Hodge \& Hodge 2048 (GH); Pegoua River, vicinity of Deux Branches, Concorde Valley, 19 Apr 1940, Hodge \& Hodge 2997 (GH); valley of Hampstead River, ca. 2 mi from mouth, La Chaudiere, 100 m, 10-14 May 1940, Hodge \& Hodge 3560 (GH); 1 mi NW of Bellevue, 19 Dec 1967, King 6315 (MO); 1 mi NE of Springfield Estate, 20 Dec 1967, King 6331 (GH); Savane David, 21 Dec 1967, King 6359 (F); Fresh Water Lake, 23 Dec 1967, King 6380 (US); Hampstead, 1903, Lloyd 638 (NY); St. Paul, trail to Morne Trois Pitons, 15²2'N, 612'W, 600 m, 22 Apr 1992, Stijfhoorn 751 (MO, NY, US); Syndicate Estate, NW slopes of Morne Diablotins, 560 m, 9 Sep 1983, Whitefoord 3518 (A, US); ibid, 10 Sep 1983, Whitefoord 3530 (US); track to Middleham Falls, 500 m, 29 Sep 1983, Whitefoord 3790 (US); Syndicate, NW slopes of Morne Diablotins, path towards Picard Gorge, 6 Oct 1984, Whitefoord 4353 (US); Parish of St. Joseph, along the Imperial Rd about $2.5 \mathrm{mi}$ N of Pont Cassé $16 \mathrm{Jul}$ 1964, Wilbur et al. 7535 (GH, MICH, US); Springfield Estate, on the Check Hall River about 6 mi NE of Roseau by rd, 1300 ft, 20 July 1964, Wilbur et al. 7703 (NY, US); 5 mi from Pont Cassé along rd to Rosalie, 22 Jul 1964, Wilbur et al. 7834 (F, MO, US). GUADELOUPE: Basse Terre, Grand Etang, 30 Jul 1980, Barrier 2413 (A); Camp Jacob, Pointe-Noire, 200-620 m, 1893, Duss 2268 (F, GH, MO, NY, US); Basse-Terre, Parc Natural, near the Crayfish Falls, 20 Feb 2001, King \& Garvey 11630 (MO); Basse-Terre, Plateau du Palmiste, NW of Gourbeyre, 400-550 m, 22 Nov 1959, Proctor 20100 (A, MICH, NY, US); Bains-Jaunes, 700 m, 16 May 1938, Questel 2275 (US); Cascade Vauchelet, 400 m, 18 Mar 1938, Questel 2297 (US); BoisRiant, 300 m, 4 May 1938, Questel 2351 (US); Trois Rivieres, 400 m, 8 Apr 1944, Questel 4989 (US); Basse-Terre, chemin menant à la cascade aux écrevisses, 17 Apr 1974, Sastre E Fournet 2510 (A); St. Claude à Gourbeyre, 450 m, 12 Nov 1924, Stehlé 35 (NY); Bains-Jaunes, 8 Feb 1937 , Stehlé 1394 (NY); Magua, 510 m, 20 Apr 1946, Stehlé 6343 (US). MARTINIQUE: Hauteurs des Trois-Ilets, Plaine des Trois-Ilets, 400-600 m, 1880, Duss 668 (NY*); Morne Rouge, Fonds Marie Reyne, Champflore, Parnasse—Fonds St. Denis, 1883-1885, Duss 1174 (NY); Morne Larcher, entre le camp Balata et le camp Colzon, Sep 1900, Duss 443 (NY*); Falaises de l'Ajoupa-Bouillon, 1901, Duss 4623 (NY*); Morne Calebasse, Feb 1868, Hahn 454 (A, NY, US); Forêt de la Celebasse, Jun 1868, Hahn 454 (GH*); ad Champflore, Mar 1870, Hahn 454 (MO*, S*); Gorges de la Falaise, Ajouba-Rouillon, 8 Mar 1978, Howard 18693 (A); trail from summit of Morne Rouge, 13-18 Mar 1979, Howard \& Howard 18891 (A, NY, US); Pitons du Carbet, Foret Departementalo Domaniale des Pitons du Carbet, LAlma, 14 42.20N, 61 05.56W, 13 May 2000, Penneys 1272 (FLAS, NY); Montagne Pelee, near parking lot, 1448.49N, 6109.01W, $835 \mathrm{~m}, 17$ May 2000, Penneys 1280 (FLAS); Morne 


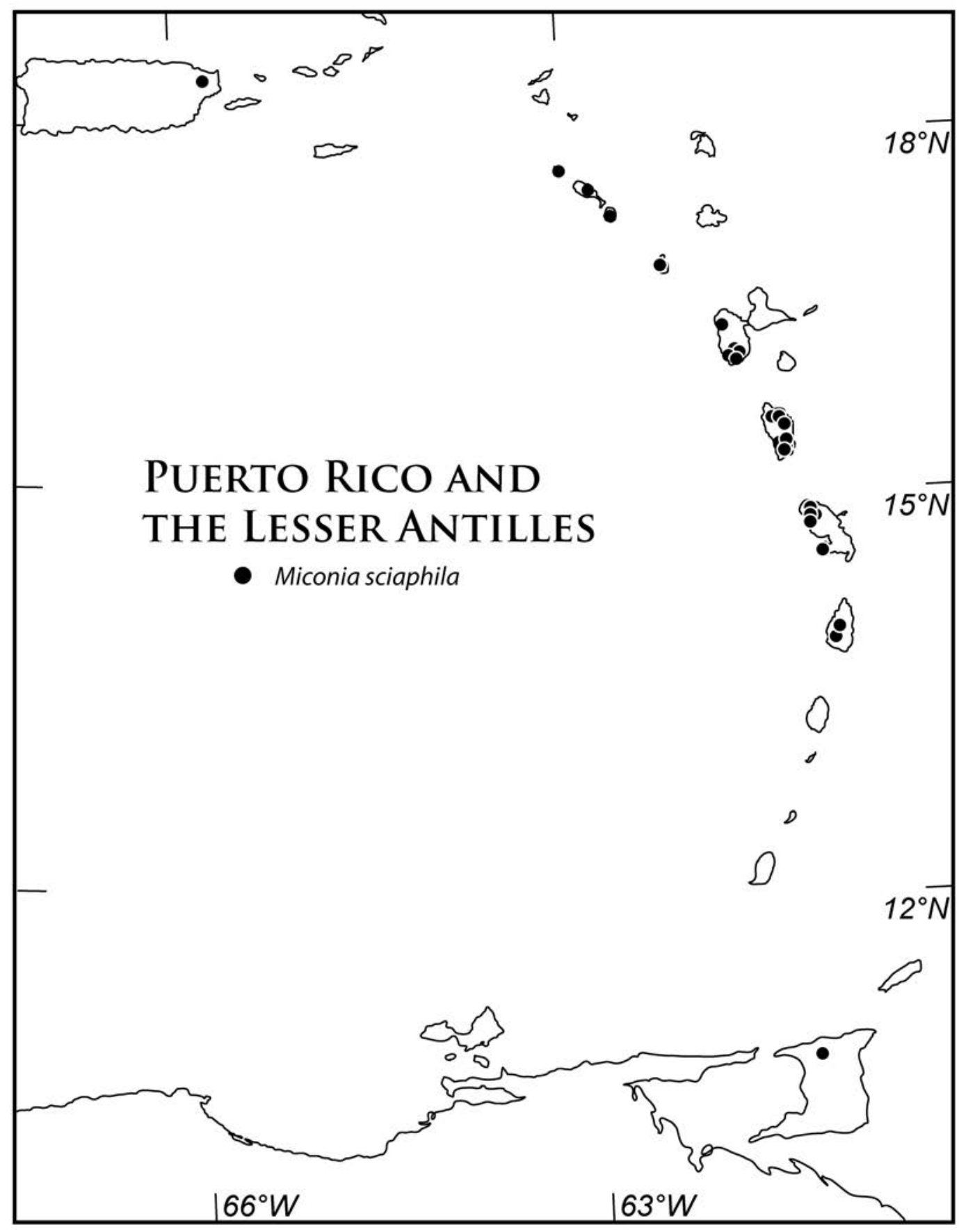

Fig. 4. Distribution of Miconia sciaphila in Puerto Rico and the Lesser Antilles. 
Calebasse, N of Morne Rouge, 650-760 m, 11 Dec 1960, Proctor 21814 (A); Basse-Pointe, Morne Balais, 900 m, 8 Apr 1984, Sastre 7660 (US*); without definite locality, Sieber 299 (MO*, US*); Quartier Bernadette, La Source, Lauiteins du Morne Vért, 650 m, 10 Aug 1942 , Stehlé 5071 (US); Parnasse, 375 m, 14 Apr 1942, Stehlé 6206 (US); Fonds Saint Denis, 700 m, 19 Mar 1940, Stehlé 6521 (US); Plateau Lavender, 580 m, 7 May 1946, Stehlé 6618 (US). NETHERLANDS ANTILLES. Saba: Trail from Windwardside village to mountaintop, 100-880 m, 1 Dec 1973, Howard 18143 (A, NY). MONTSERRAT: Hermitage, 500 m, 15 Nov 1944, Beard 443 (A, MO, NY, US); area of Gages Soufriere, 5-14 Jan 1961, Howard \& Howard 15090 (A); at Lang's Soufriere, Paradise Estate, 5-14 Jan 1961, Howard \& Howard 15170 (A); river valley below Gage's Upper Soufriere, 19 Mar-16 Apr 1979, Howard et al. 19009 (A, NY); W spur of Chance's Mountain, Soufriere Hills, 1000-2000ft, 9 Feb 1959, Proctor 19085 (A, US); Chaners Mountain, 2000 ft, 26 Jan 1907, Shafer 250 (F, NY, US); Woodlands mountains, 16 Feb 1907, Shafer 571 (F, NY, US). SAINT KITTS AND NEVIS. Nevis: vicinity of Dodans Water Source, 1300-1800, 7 Mar 1959, Proctor 19415 (A). St. Kitts: ravine, Molyneux Estate, 8 Sep-5 Oct 1901, Britton \& Cowell 316 (NY, US); Molyneux Water Source, ravine, 1000-1200ft, 27 Feb 1959, Proctor 19282 (A, MO, US). SAINT LUCIA: Savanne Edmund district, SE of Piton Troumassée, 1800-2000ft, 14 Apr 1968, Proctor 17639 (A, US); Savanne Edmund district, SE of Piton Troumassée, 11-12 May 1958, Proctor 17955 (A, US); Barre de l'Isle, 800 ft, Nov 1969, Sturrock 621 (A). TRINIDAD: Without definite locality, 1873, Sieber 59 (M* [M-0165408] digital image seen, MO*, $\mathrm{P}^{*}$ [viewed at GBIF]; photo of specimen at Herb. Cons. Bot. Geneva: F, GH).

Miconia sciaphila occurs primarily in the Lesser Antilles, but its range extends into the Greater Antilles in Puerto Rico. The species is rather variable morphologically, and especially some of the collections from Martinique and Guadeloupe have a rather distinctive indumentum of globular-stellate to elongate, manybranched hairs (likely derived from Sagraea-type hairs, through the proliferation of non-glandular branches), instead of the more commonly encountered short to elongate, unbranched or distally, poorly branched hairs with bullate cells. These collections are indicated by an asterisk in the specimens examined, and such plants occasionally have been considered as specifically distinct (see de Candolle 1828; Naudin 1852; Triana 1871). A few intermediate collections, however, have been seen (e.g., Stehlé 1394, NY) and we tentatively consider Clidemia latifolia (Desr.) DC. to be conspecific with the species here considered as Miconia sciaphila (in agreement with Howard 1989; Michelangeli \& Bécquer 2012). Miconia sciaphila is easily distinguished from M. berteroi (see discussion under that species) and from other species of sect. Sagraea growing in the Greater Antilles (see key).

Miconia sciaphila sometimes has been confused with M. vincentiana (Urb.) Judd \& Ionta (see Judd \& Ionta 2017), but is easily distinguished by its stems with stout, elongate, eglandular hairs from 1.5-6 mm long, in contrast with those of M. vincentiana, which are thinner and do not exceed $1 \mathrm{~mm}$ in length. The two species are allopatric, as M. vincentiana is endemic to the island of St. Vincent. A third species, Miconia guadalupensis (DC.) Judd, Ionta, \& Majure, comb nov. ${ }^{1}$, restricted to Guadeloupe and Dominica, could also be confused with M. sciaphila. Miconia guadalupensis, however, can be distinguished by its quadrangular stems that are usually obscurely to strongly longitudinally winged, with elongate, smooth-sided, eglandular hairs to only $0.7 \mathrm{~mm}$ long, and lacking slender hairs having bullate cells. In addition, it bears paniculate to elongate cymose inflorescences with the flowers more or less pseudoverticillate (vs. inflorescences broader and flowers non pseudoverticillate in M. sciaphila), and its leaves are acute to rounded at the base (vs. usually obtuse to slightly cordate).

Determination of type material of Miconia sciaphila has been difficult. There is a specimen consisting of only a single leaf collected by O. Swartz at S (\#11-16869) and this could possibly be a syntype, but this cannot be confirmed because the specimen is without date or locality data. Interestingly, on this specimen is an annotation by R.A. Howard stating that the "Lectotype of Melastoma umbrosa Sw. is Masson s.n. (BM)" but this suggested lectotypification was never published. Additionally, there is a possible duplicate of the Masson s.n. specimen at LINN. The specimen here chosen as the lectotype, Fahlberg s.n., is indicated as type material on the sheet and well matches the protologue.

Unfortunately, the epithet "umbrosa" (meaning "shady") is already occupied in the genus Miconia, thus the species requires a new name. We have chosen the name Miconia sciaphila (the epithet meaning "shadeloving") in order to logically connect the new name to the original one. Beautiful illustrations of this species have been published in Vahl (1798-1799), Little et al. (1974), and Fournet (1978).

\footnotetext{
${ }^{1}$ Sagraea guadalupensis DC., Prodr. 3:170. 1828. Type: Guadeloupe, Bertero s n. (holotype: G-DC [G-DC 00310858] digital image!; isotype: M [M 0165393] digital image!).
} 
3. Miconia septuplinervia (Cogn.) Judd \& Ionta, comb. nov. Clidemia septuplinervia Cogn. in C.F.P. von Martius, Fl. Bras. 14(4):506. 1888. Type: PERU. Prov. MAynas: paludibus sylvestribus ad Yurimaguas, 1830, E.F. Poeppig 2203 (LeCtotyPE, designated here: BR [BR 0000005184453] digital image!, ISOLECTOTYPE: BR [BR 0000005184125] digital image!; PHOTO OF TYPE MATERIAL, nOW destroyed, at B: F!).

Ossaea trichocalyx Pittier, J. Wash. Acad. Sci. 13:391. 1923. Type: PANAMA: along Caño Quebrado, Canal Zone, 14 Jun 1914, H. Pittier 6667 (ноLотуре: VEN [VEN 10570] digital image!).

Unbranched or poorly branched liana-like shrub or a liana, to $2(-4) \mathrm{m}$, with stems frequently producing adventitious roots. Indumentum of minute, multicellular, short-stalked, gland-headed hairs that have furrows between the cells of the head (i.e., Sagraea-type hairs), and these sometimes with few, non-glandular basal branches or elongated, slender, simple or poorly and shortly branched, with \pm bulging cells, and also multicellular, simple, elongate, smooth-sided, eglandular hairs (but these restricted to leaf margin and sometimes also adaxial surface of lamina) and gland-headed hairs (but these restricted to the hypanthium and calyx teeth). Young stems slightly quadrangular to terete, with moderate to dense Sagraea-type hairs, these \pm persistent, and hairs of the nodes similar to those of internodal regions; internodes $1.5-16 \mathrm{~cm}$ long, the nodes not or only slightly swollen, with faint nodal line. Leaves slightly anisophyllous; petiole $0.3-6 \mathrm{~cm}$ long (but appearing longer, due to narrowly decurrent leaf base), terete and dorsally grooved, the indumentum of moderate to dense Sagraea-type hairs, and these sometimes with a few, short, basal, non-glandular branches; blade (8-) 10-37.5 cm long, (2.8-) 4-16.3 cm wide, ovate to elliptic, flat, membranaceous to chartaceous, the apex acuminate, the base decurrent to long-decurrent, the margin plane, usually entire, occasionally very obscurely and sparsely serrate, the largest teeth (when present) to $0.3 \mathrm{~mm}$, and ciliate, with elongate, eglandular hairs, $0.2-1$ $\mathrm{mm}$ long, and these terminating obscure teeth, when such present; venation acrodromous, with prominent midvein and 3 or 4 secondary vein pairs, \pm suprabasal, the outermost 1 or 2 pairs inconspicuous and sometimes also intramarginal, if only one pair then positioned $0.2-0.5 \mathrm{~mm}$ from margin, or if 2 pairs then the inner pair $1-10 \mathrm{~mm}$ and the outer pair $0.2-2.2 \mathrm{~mm}$ from margin (or ending below leaf midpoint), the inner 2 pairs conspicuous, positioned $7-60 \mathrm{~mm}$ and $1.5-28 \mathrm{~mm}$ from margin, respectively, the tertiary veins numerous, percurrent, oriented subperpendicular to midvein and 2.5-15 mm apart, joined by numerous percurrent quaternary veins, and the higher order veins orthogonal-reticulate; adaxial surface green, the midvein, prominent secondary, and often tertiary veins with Sagraea-type hairs, and these often with a few, basal, non-glandular branches, and sometimes also elongate, slender, unbranched or poorly and shortly branched hairs with \pm bulging cells, the other veins with Sagraea-type hairs (and these sometimes few-branched), and lamina with Sagraea-type hairs (and these sometimes few-branched) and sometimes also with sparse, elongated, smoothsided, eglandular hairs, 0.1-0.4 mm long, \pm deciduous, the midvein impressed, other veins \pm flat; abaxial surface pale green, with Sagraea-type hairs, these sometimes with a few non-glandular branches, and occasionally elongate, slender, unbranched or poorly branched, and with bullate or papillate cells, the midvein and major secondary veins moderately to strongly raised, the tertiary and minor secondary veins slightly raised, and quaternary to higher-order veins very slightly raised to flat; domatia present and pocket-like, at junction of major secondary veins and midvein, or absent. Inflorescences axillary, usually cauliflorous (i.e., on old, leafless nodes of older stems, but occasionally in axils of leaves), 2-ca. 50-flowered, basally branched, fasciculate cymes, with each axis having $0-1$ major branch-pairs, with 1 inflorescence per leaf axil (but often appearing to be several due to basal branching), $1-3.5 \mathrm{~cm}$ long, $1-5.5 \mathrm{~cm}$ in diameter, proximal segment of lowermost inflorescence branches to $1-12.5 \mathrm{~mm}$ long, the ultimate axes (pseudopedicels) $0.5-8 \mathrm{~mm}$ long, and flowers well separated to densely clustered, the inflorescence branches with moderate to dense Sagraea-type hairs; peduncle 0-2 mm long, with indumentum of Sagraea-type hairs; bracts $0.3-1 \times 0.4-0.7 \mathrm{~mm}$, triangular to narrowly triangular, with acute to acuminate apex, persistent to deciduous, with Sagraea-type hairs; bracteoles 0.2-0.3 $\times$ ca. $0.3 \mathrm{~mm}, \pm$ triangular, with acute to acuminate apex, \pm persistent, with Sagraea-type hairs. Flowers 4-merous, radial, with pedicel 0.3-3 mm long. Hypanthium 2.5-3.4 mm long, \pm cylindrical, not constricted, the free portion $0.8-1.6 \mathrm{~mm}$ long, $0.9-1.3 \mathrm{~mm}$ wide at the base of the calyx, the outer surface with moderate to dense Sagraea-type hairs, and occasionally also with a few multicellular, simple, elongate, gland-headed hairs, the 
inner surface smooth to slightly ridged, with a few Sagraea-type hairs, androecial fringe absent. Calyx lobes 4 , separate in bud, $0.3-0.55 \times 0.8-1.4 \mathrm{~mm}$, triangular to shallowly so, the apex usually rounded, occasionally obtuse to acute, the margins entire, abaxially with Sagraea-type hairs and adaxially glabrous or with a few Sagraea-type hairs; calyx tube $0.15-0.4 \mathrm{~mm}$ long, usually not tearing between lobes, glabrous or with a few Sagraea-type hairs on adaxial surface. Calyx teeth present, 4, 0.9-3 mm long, borne dorsally on calyx lobes, spreading to recurved, terete, with acute apex, and with 1 or 2 to several multicellular, simple, elongate, glandheaded (but these occasionally absent) and Sagraea-type hairs. Petals 4, white to pink or rose, 1.3-2.5 $\times 0.6-1.2$ $\mathrm{mm}$, ovate to oblong, spreading to recurved at anthesis, the adaxial surface glabrous, the abaxial surface glabrous or with a single \pm apical multicellular elongate hair, the apex rounded, sometimes slightly notched, the base slightly narrowed or broad and parallel-sided, the margin entire. Stamens $8, \pm$ isomorphic, geniculate near apex of filament, \pm radially arranged; staminal filament $1.3-1.8 \mathrm{~mm}$ long, flattened-terete, glabrous, white; anther thecae $1.2-2 \times 0.2-0.3 \mathrm{~mm}$, ovate to oblong-linear, white, opening by small, dorso-apical pore, the connective slightly expanded and basally extended, not appendaged. Ovary 4-locular, 2-2.4 mm long, 1.3-1.7 mm wide, $2 / 3$ to $3 / 4$-inferior, with a cylindrical apical collar surrounding the style, the collar slightly lobed, and without a crown, although with short, glandular hairs, especially on the collar, with axile placentation, the ovules numerous, borne on expanded placenta; style 3.5-4.7mm long, straight, terete, white to pink, glabrous or with a few glandular hairs at extreme base; stigma \pm capitate, $0.25-0.5 \mathrm{~mm}$ wide. Berries $4-9.5 \mathrm{~mm}$ long, 3.5-6.5 mm in diameter (expanding greatly at maturity), globose to ellipsoid or ovoid, red when immature and turning bright sky-blue at maturity, with usually only dense Sagraea-type hairs but rarely also with elongate, gland-headed hairs. Seeds ca. $0.3 \mathrm{~mm}$ long, hemispheric-obovoid, with elliptic, flat, hilum, covering $3 / 4$ to $4 / 5$ length of seed; testa cells clearly bullate; appendage absent.

Phenology.-Recorded in flower every month of the year.

Distribution and habitat.-In the Antilles Miconia septuplinervia grows only in Jamaica (eastern Blue Mountains and John Crow Mountains; Fig. 5) in moist montane forests, thickets, and rainforests from 300760 m. Widespread in the Neotropics, from Mexico through Central America (Belize, Costa Rica, Guatemala, Honduras, Nicaragua, Panama) to northern South America (Brazil, Colombia, Ecuador, French Guiana, Peru, Surinam, Venezuela), inhabiting rainforests and montane forests from 0-1200 m.

Additional specimens examined. JAMAICA. Portland Parish: John Crow Mountains, path to Proctor's Pool, ca. 1750-2250 ft, 27 Jul 1963, Crosby et al. (MICH); E slope of the John Crow Mts., 1.5-2.5 mi SW of Ecclesdown, 1500-2500 ft, 17 Jun 1959, Proctor 19740 (A, IJ, NY); E slope of the John Crow Mts., 1.5-2 mi SW of Ecclesdown, 1500-2000 ft, 1 Sep 1962, Proctor 22698 (IJ, MICH, NY); John Crow Mountains, ca. 6 mi by rd S of Sherwood Forest, 1200-1500 ft, 13 Oct 1976, Proctor 36448 (IJ); John Crow Mountains, 1 mi S of Ecclesdown, 1000-1200 ft, 17 Jun 1959, Webster et al. 8333 (S, US). St. Thomas Parish: along the Wild Cane River, 1.1 mi due SE of Macungo Hill, ca. 1500 ft, 14 May 1968, Proctor 28717 (FLAS, IJ).

Despite the widespread distribution of Miconia septuplinervia in the Neotropics, the species is rather uniform in its morphology, and the populations of Jamaica are indistinguishable from those of continental regions. (In addition to the Jamaican specimens cited above, I have examined 34 specimens of this species from across the Neotropics, e.g., Brazil: Daly et al. 10315; Colombia: Callejas 1052; Costa Rica: Mora 773; Ecuador: Øllgaard 38991; French Guiana: Mori \& Gracie 18731; Guatemala: Contreras 7894; Nicaragua: Proctor et al. 27094; Panama: Busey 325; Peru: Graham 2285; Venezuela: Steyermark et al. 119678, all at NY.) The species has berries that at maturity are intensely sky-blue, and are thus similar in color to those of the members of the cerulean fruit subclade of the Brevicyma clade (Ionta, unpublished data). The phylogenetic placement of M. septuplinervia, i.e., nearly basal within the section, suggests that these intensely blue fruits have evolved in parallel. Its distinctive lianous habit, with the plants unbranched or only poorly branched and producing adventitious roots, easily distinguishes this species from all other members of the section in the Greater Antilles.

There are two specimens of Poeppig 2203 at BR, and I chose \#5164453 as the lectotype (instead of \#5184125) because \#5164453 has flowers/young fruits (in a packet) in addition to the mounted leaf with its attached stem, while the specimen \#5184125 is merely a vegetative branch.

Two beautiful color illustrations of this species (as Ossaea trichocalyx Pittier) are available online (website of the Royal Botanical Garden, Madrid; see J.C. Mutis). 


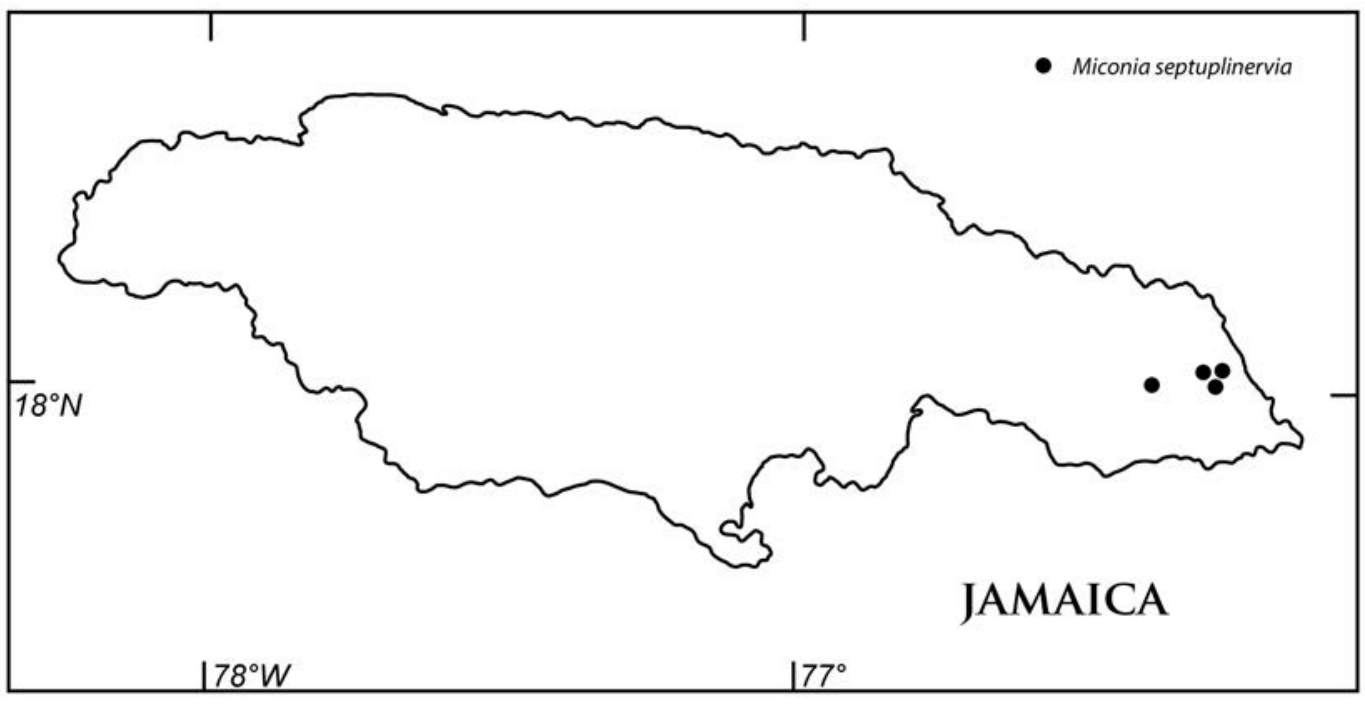

Fıg. 5. Distribution of Miconia septuplinervia in Jamaica.

\section{ACKNOWLEDGMENTS}

We thank Norris Williams, Keeper of the University of Florida Herbarium (FLAS) and Kent Perkins, Collections Manager, for assistance in processing specimens. We also thank the curators and staff of the herbaria (A, F, GH, JBSD, MICH, MO, NY, S, US), who generously provided specimens on loan. Keron C. St. E. Campbell graciously assisted in the visit of the first and second authors to the herbarium (IJ) of the Natural History Museum of Jamaica, Institute of Jamaica. Milcíades Mejía, Thomas A. Zanoni, Daisy Castillo, Alain H. Liogier, Teodoro Clase, Ricardo García, Francisco Jiménez, and Brígido Peguero assisted in several visits of the first author to the herbarium (JBSD) of the Jardin Botánico Nacional, Dominican Republic. We also thank administrators of the Herbario Rafael M. Moscoso (UCMM) at the Pontificia Universidad Catolica Madre y Maestra, Santiago, República Dominicana, for their assistance. Alan Prather assisted the first author during his visit to the Michigan State University Herbarium (MSC). We appreciate the assistance in fieldwork provided by J. Dan Skean, Jr. We appreciate the very helpful comment of the two reviewers: Fabian A. Michelangeli and J. Dan Skean, Jr. This research was supported, in part, by National Science Foundation Grant BSR-0818399, and we thank Fabian A. Michelangeli for his administrative and professional assistance in connection with this grant-supported project.

\section{REFERENCES}

Alain, Bro. (= A.H. LIoGier). 1957. Flora de Cuba. Vol. 4. Dicotiledóneas: Melastomataceae a Plantaginaceae. Cont. Ocas. Mus. Hist. Nat. Col. "De La Salle." Havana, Cuba.

AxelRod, F.S. 2011. A systematic vademecum to the vascular plants of Puerto Rico. Sida, Bot. Misc. No. 34:1-428.

Bécquer, E.R., K.M. Neubig, W.S. Judd, F.A. Michelangel, J.R. Aвbott, \& D.S. Penneys. 2008. Preliminary molecular phylogenetic studies in Pachyanthus (Miconieae, Melastomataceae). Bot. Rev. 74:37-52.

Bécquer, E.R., W.S. Judd, \& L.C. Majure. 2017/18. Taxonomic revision of Miconia sect. Calycopteris (Melastomataceae, Miconieae) in Cuba. Brittonia 70:90-110. doi:10.1007/s 12228-017-9493-1.

BRIQUet, J. 1906. Regles Interantionales de la Nomenclature Botanique. Verlag von Gustav Fischer, Jena, Germany.

Cogniaux, A. 1891. Melastomataceae. In: A. de Candolle \& C. de Candolle, eds. Monographiae phanerogamarum. 7. Masson, Paris. Pp. 1-1256.

DE CANDolle, A. 1828. Clidemia latifolia. Prodromus systematis naturalis regni vegetabilis 3:159. 
Fournet, J. 1978. Flore illustrée des phanérogames de Guadeloupe et de Martinique. Institut National de la Recherche Agronomique, Paris.

Gamba, D. \& F. Almeda. 2014. Systematics of the Octopleura Clade of Miconia (Melastomataceae: Miconieae) in Tropical America. Phytotaxa 179:1-174.

Goldenberg, R., D.S. Penneys, F. Almeda, W.S. Judd, \& F.A. Michelangeli. 2008. Phylogeny of Miconia (Melastomataceae): Patterns of stamen diversification in a megadiverse Neotropical genus. Int. J. PI. Sci. 169:963-979.

Goldenberg, R., F. Almeda, M.K. Caddah, A.B. Martius, J. Meirelles, F.A. Michelangeli, \& M. Weiss. 2013. Nomenclatur botanicus for the Neotropical genus Miconia (Melastomataceae: Miconieae). Phytotaxa 106:1-171.

Howard, R.A. 1989. Flora of the Lesser Antilles: Leeward and Windward Islands. Vol. 5. Dicotyledoneae - Part 2. Arnold Arboretum, Harvard Univ., Jamaica Plain, Massachusetts, U.S.A.

IontA, G.M., W.S. Judd, J.D. SkEAN, \& C.K. McMullen. 2012. Two new species of Miconia sect. Sagraea (Melastomataceae) from the Macaya Biosphere Reserve, Haiti. J. Bot. Res. Inst. Texas 6:37-44.

JUDD, W.S. 1986. Taxonomic studies in the Miconieae (Melastomataceae). I. Variation in inflorescence position. Brittonia 38:150-161.

JUDD, W.S. 1989. Taxonomic studies in the Miconieae (Melastomataceae). III. Cladistic analysis of axillary-flowered taxa. Ann. Missouri Bot. Gard. 76:476-495.

JUDD, W.S. 2007. Revision of Miconia sect. Chaenopleura (Miconieae, Melastomataceae) in the Greater Antilles. Syst. Bot. Monogr. 81:1-235.

JUDD, W.S. \& J.D. SKEAN, JR. 1991. Taxonomic studies in the Miconieae (Melastomataceae). IV. Generic realignments among terminal-flowered taxa. Bull. Florida Mus. Nat. Hist., Biol. Sci. 36:25-84.

JudD, W.S. \& G.M. IONTA. 2013. Taxonomic studies in the Miconieae (Melastomataceae). X. Revision of the species of the Miconia crotonifolia complex. Brittonia 65:66-95.

JUdD, W.S. \& G.M. IontA. 2017. Miconia vincentiana (Melastomataceae: Miconieae), a curious endemic to St. Vincent. 2017. J. Bot. Res. Inst. Texas 11:335-342.

Judd, W.S., E.R. Bécquer, \& L.C. MAJure. 2014a. Taxonomic studies in the Miconieae (Melastomataceae). XI. A revision of Miconia sect. Calycopteris on Hispaniola. Brittonia 66:216-249.

Judd, W.S., E.R. Bécquer, J.D. SkeAN, JR., \& L.C. Majure. 2014b. Taxonomic studies in the Miconieae (Melastomataceae). XII. Revision of Miconia sect. Miconiastrum, with emphasis on the Miconia bicolor complex. J. Bot. Res. Inst. Texas 8:457-491.

Judd, W.S., L.C. Majure, G.M. IontA, \& K.M. Neubig. 2015a. Taxonomic studies in the Miconieae (Melastomataceae). XIII. Systematics of Miconia subcompressa, a Hispaniolan endemic comprised of three eco-geographic subspecies. Phytotaxa 197:61-83.

Judd, W.S., L.C. Majure, J.D. Skean, JR., \& K.M. Neubig. 2015b. Miconia abscondita (Melastomataceae: Miconieae), a new species from the Massif de la Hotte, Haiti: Rediscovered in herbaria after being hidden for nearly nine decades. Rhodora 117:317-341.

Judd, W.S., E.R. Bécquer, \& L.C. Majure. 2017. First collection of Miconia turquinensis (Melastomataceae: Miconieae) with flowers, and comparison with M. remotiflora, a putative close relative. J. Bot. Res. Inst. Texas 11:161-167.

Lıogier, A.H. 2000. La flora de la Española. Vol. IX. Melastomataceae. Jardin Botánico Nacional “Dr. Rafael Ma. Moscoso." Instituto Tecnológico de Santo Domingo, Santo Domingo, República Dominicana.

LIoGier, H.A. (= A.H. Liogier). 1995. Descriptive flora of Puerto Rico and adjacent islands. Vol. IV. Melastomataceae to Lentibulariaceae. Editorial de la Universidad de Puerto Rico, Rio Piedras.

Little, E.L., JR., R.O. Woodbury, \& F.H. Wadsworth. 1974. Trees of Puerto Rico and the Virgin Islands. Vol. 2. Agricultural Handbook No. 449. Forest Service. U.S. Department of Agriculture, Washington, D.C., U.S.A.

MAJURE, L.C. \&W.S. JUDD. 2013. Miconia phrynosomaderma (Melastomataceae: Miconieae), a new species from the Massif du Nord, Haiti, and sixteen new names and combinations. J. Bot. Res. Inst. Texas 7:265-274.

Majure, L.C., W.S. Judd, G.M. IontA, J.D. SkeAn, JR., K.M. Neubig, \& E.R. Bécquer. 2014. Miconia cineana, a new species from the Massif de la Hotte, Haiti, based on morphological and molecular evidence. Syst. Bot. 39:906-914.

MAJURE, L.C., W.S. Judd, \&F.A. MichelAngel. 2014/15. Taxonomic revision of the Greater Antillean Pseudolima clade of Miconia (Miconia sect. Krugiophytum: Miconieae: Melastomataceae). Brittonia 67:11-18. doi:10.1007/512228-014-9349-x.

Majure, L.C., K.M. Neubig, J.D. Skean, JR., E.R. Bécquer, \& W.S. Judd. 2015. Evolution of the sandpaper clade (Miconieae, Melastomataceae). Int. J. PI. Sci. 176:607-626.

MAJURE, L.C., E.R. Bécquer, \& W.S. JudD. 2016. Revision of the Lima clade (Miconia sect. Lima, Miconieae, Melastomataceae) of the Greater Antilles. PhytoKeys 72:1-99. 
Martin, C.V., D.P. Little, R. GoldenberG, \& F.A. Michelangeli. 2008. A phylogenetic evaluation of Leandra (Miconieae, Melastomataceae) based on ITS data and its implications on inflorescence position. Taxon 53:279-290.

Michelangeli, F.A. \& E.R. Bécquer. 2012. Melastomataceae. In: P. Acevedo-Rodríguez \& T.M. Strong. Catalogue of seed plants of the West Indies. Smithsonian Contr. Bot. No. 98. Smithsonian Institution Scholarly Press, Washington, D.C., U.S.A. Pp. 531-652.

Michelangel, F.A., W.S. Judd, D.S. Penneys, J.D. Skean, JR., E.R. Bécquer, R. Goldenberg, \& C.V. Martin. 2008. Multiple events of dispersal and radiation of the tribe Miconieae (Melastomataceae) in the Caribbean. Bot. Rev. 74:53-77.

Michelangeli, F.A., F. Almeda, R. Goldenberg, W.S. Judd, E.R. Bécquer, \& T.M. Tulig. 2009 onward. A complete web-based monograph of the tribe Miconieae (Melastomataceae). (http://sweetgum.nybg.org/melastomataceae). The New York Botanical Garden, Bronx, New York, U.S.A.

Michelangel, F.A., F. Almeda, M. Alvear, E.R. Bécruer, J. Burke, M.K. Caddah, R. Goldenberg, G.M. Ionta, W.S. Judd, L.C. Majure, J. Meirelles, A.N. Nicolas, G. Ocampo, D.S. Penneys, J.D. Skean, JR., \& C. Ulloa Ulloa. 2016. Proposal to conserve Miconia nom. cons. against the additional names Maieta and Tococa (Melastomataceae: Miconieae). Taxon 65:892-893.

Michelangeli, F.A., A.N. Nicolas, G. Ocampo, R. Goldenberg, F. Almeda, W.S. Judd, E.R. Bécquer, J.D. Skean, JR., R. Kriebel, K. Sosa, M.K. Caddah, G.M. Ionta, D.S. Penneys, M. Alvear, J.M. Burke, L.C. Majure, \& M. Reginato. Submitted. Historical biogeography of the Neotropical tribe Miconieae (Melastomataceae) reveals a pattern of progressive colonization from Amazonia to other Neotropical forests. J. Biogeog.

Moscoso, R.M. 1943. Catalogus florae domingensis. Parte 1. Spermatophyta. Universidad de Santo Domingo, Santo Domingo, Dominican Republic.

Mutis, J.C. 2017. Clidemia septuplinervia, as Ossaea trichocalyx. Proyecto de digitalización de los dibujos de la Real Expedición Botánica del Nuevo Reino de Granada (1783-1816), dirigida por José C. Mutis. DIV. III A-2631 and A-2634. www.rjb.csic.es/icones/mutis. Accessed Aug 2017.

NAUDIN, C. 1852. Staphidiastrum latifolium. In: Melastomatacearum: Monographicae decriptionis et secundum affinitates distributionis. Ann. Sci. Nat., Bot. sér. 3, 17:326.

Nicolson, D.H. 1991. Flora of Dominica, Part 2: Dicotyledoneae. Smithsonian Contr. Bot. No. 77. Smithsonian Institution Press, Washington, D.C., U.S.A.

Penneys, D.S., F. A. Michelangeli, W.S. Judd, \& F. Almeda. 2010. Henriettieae: a new Neotropical tribe of berry-fruited Melastomataceae. Syst. Bot. 35:783-800.

Penneys, D.S. \& W.S. JudD. 2011. Phylogenetics and morphology in the Blakeeae (Melastomataceae). Int. J. PI. Sci. 174:802-817.

Proctor, G.R. 1972. Melastomataceae. In: C.D. Adams. Flowering plants of Jamaica. University of the West Indies, Mona, Jamaica. Pp. 529-548.

Solt, M.L. \& J.J. WURDACK. 1980. Chromosome number in the Melastomataceae. Phytologia 47:199-220.

THIERS, B.M. [continuously updated]. Index Herbariorum: A global directory of public herbaria and associated staff. New York Botanical Garden's Virtual Herbarium. http://sweetgum.nybg.org/ih/

TRIANA, J. 1871. Les Mélastomacées. Trans. Linnean Soc. London 28:1-147.

Turland, N.J., J.H. Wiersema, A.M. Monro, Y.-F. Deng \& L. Zhang. 2017. XIX International Botanical Congress: Report of Congress action on nomenclature proposals. Taxon 66:1234-1245.

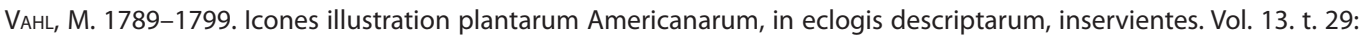
Melastoma umbrosa. Hauniae, impensis auctoris.

Wheeler, Q.D. \& N.I. Platnick. 2000. The phylogenetic species concept (sensu Wheeler and Platnick). In: Q.D. Wheeler \& R. Meier, eds. Species concepts and phylogenetic theory: A debate. Columbia University Press, New York, U.S.A. Pp. 55-69.

WILSON, K.L. 2017. Report of the General Committee: 18. Taxon 66:742-744.

WURDACK, J.J. 1972. Certamen Melastomataceis XVIII. Phytologia 22:399-418.

WURDACK, J.J. 1980. Melastomataceae. In: G.H. Harling \& B. Sparre, eds. Flora of Ecuador. Vol. 13. University of Göteborg \& Riksmuseum, Stockholm, Sweden. Pp. 1-416.

WURDACK, J.J. 1986. Atlas of hairs for Neotropical Melastomataceae. Smithsonian Contr. Bot. No. 63. Smithsonian Institution Press, Washington, D.C., U.S.A. 